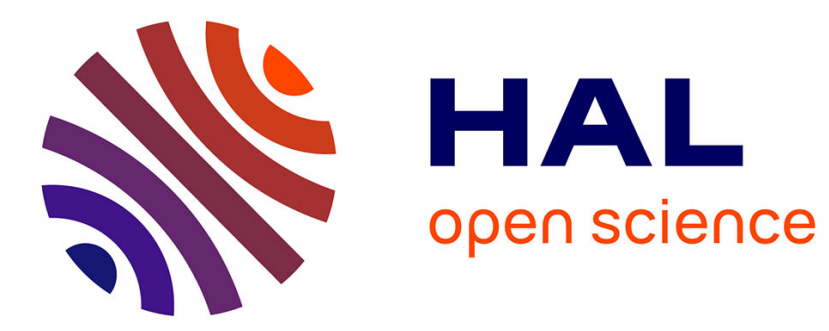

\title{
Agarophyton transtasmanicum sp. nov., from Australia and New Zealand
}

Maren Preuss, Narongrit Muangmai, Wendy A Nelson, Marie-Laure

Guillemin, John A West, Giuseppe C Zuccarello

\section{To cite this version:}

Maren Preuss, Narongrit Muangmai, Wendy A Nelson, Marie-Laure Guillemin, John A West, et al.. Agarophyton transtasmanicum sp. nov., from Australia and New Zealand. Phycologia, In press, 10.1080/00318884.2020.1734435 . hal-02570988

\section{HAL Id: hal-02570988 \\ https://hal.sorbonne-universite.fr/hal-02570988}

Submitted on 12 May 2020

HAL is a multi-disciplinary open access archive for the deposit and dissemination of scientific research documents, whether they are published or not. The documents may come from teaching and research institutions in France or abroad, or from public or private research centers.
L'archive ouverte pluridisciplinaire HAL, est destinée au dépôt et à la diffusion de documents scientifiques de niveau recherche, publiés ou non, émanant des établissements d'enseignement et de recherche français ou étrangers, des laboratoires publics ou privés. 
Maren Preuss $^{1, *}$, Narongrit Muangmai ${ }^{2,3}$, Wendy A. Nelson ${ }^{4,5}$, Marie-Laure Guillemin ${ }^{6,7}$, John A. West ${ }^{8}$ and Giuseppe C. Zuccarello ${ }^{1}$

${ }^{1}$ School of Biological Sciences, Victoria University of Wellington, P.O. Box 600, Wellington 6140, New Zealand

${ }^{2}$ Department of Fishery Biology, Faculty of Fisheries, Kasetsart University, Bangkok 10900, Thailand

${ }^{3}$ Graduate School of Integrated Science for Life, Hiroshima University, Hiroshima 739-8528, Japan

${ }^{4}$ National Institute of Water and Atmospheric Research, Private Bag 14-901, Wellington 6241, New Zealand

${ }^{5}$ School of Biological Sciences, University of Auckland, Private Bag 92-019, Auckland 1142, New Zealand

${ }^{6}$ CNRS, Sorbonne Université, UMI 3614, Evolutionary Biology and Ecology of Algae, Station Biologique de Roscoff, CS 90074, 29688 Roscoff, France

${ }^{7}$ Instituto de Ciencias Ambientales y Evolutivas, Facultad de Ciencias, Universidad Austral de Chile, Valdivia, Chile 
${ }^{8}$ School of BioSciences, University of Melbourne, Parkville, VIC 3010, Australia

*Corresponding author: E-mail: Maren142@web.de

Running title: Agarophyton transtasmanicum sp. nov. 


\begin{abstract}
The Gracilariaceae is a species rich family, with a number of members having high commercial value as sources of agar. Members of this family are also known for their phenotypic plasticity and convergent morphologies resulting in considerable taxonomic confusion. Over the past two decades, two species of Agarophyton (previously part of Gracilaria) have been recognized in New Zealand with very similar morphologies and growth habits, and they have been incorrectly grouped as Agarophyton chilense. Agarophyton chilense is distributed in Chile and New Zealand and is genetically distinct from Agarophyton sp. from Australia and New Zealand. We name this new species A. transtasmanicum sp. nov. Morphologically A. transtasmanicum has fewer medullary cell layers and a more abrupt transition in cell size between cortex and medulla than $A$. chilense. The cox 1 and $r b c \mathrm{~L}$ dataset grouped A. transtasmanicum as sister to A. tenuistipitatum with high support. Clarifying the distinctions between A. chilense and A. transtasmanicum will enable further research, including investigating differences in distribution patterns, physiology and ecology, and chemical composition between these two Agarophyton species.
\end{abstract}

KEYWORDS: cox1, ITS1; Phylogeny; rbcL; Rhodophyta; Systematics; Taxonomy 


\section{INTRODUCTION}

The Gracilariaceae is one of the most species-rich and commercially important red algal families. Some Gracilariaceae members are known for for their phenotypic plasticity, relatively simple and convergent morphologies. Due to their commercial importance and classification challenge, numerous taxonomic studies have been done on the group (e.g., Abbott et al. 2004). Some genera have been proposed and later discarded, especially lineages related to Gracilaria. The stability and utility of the genus Hydropuntia has been controversial, with authors both accepting (Gurgel \& Fredericq 2004; Gurgel et al. 2018) and not accepting this change (Iha et al. 2018; Lyra et al. 2015), plus a name was suggested, but not formally proposed, for a lineage containing one of the most important commercial Gracilaria's, Gracilaria chilensis C.J.Bird, McLachlan \& E.C.Oliveira, and a well-known invasive alga, Gracilaria vermiculophylla Ohmi (Gurgel \& Fredericq 2004). A recent taxonomy has accepted both Hydropuntia, and formally described a new genus, Agarophyton, for the lineage containing Gracilaria chilensis (Guiry et al. 2018; Gurgel et al. 2018).

Agarophyton chilense (C.J.Bird, McLachlan \& E.C.Oliveira) Gurgel, J.N.Norris \& Fredericq and a sister species, A. tenuistipitatum (C.F.Chang \& B.-M.Xia) Gurgel, J.N.Norris \& Fredericq, are the second most intensively cultivated red algal group world-wide with 3.9 million tonnes harvested per year (after Eucheuma with 10.2 million tonnes, Ferdouse et al. 2018). Plus, the invasive nature of A. vermiculophyllum (Ohmi) Gurgel, J.N.Norris \& Fredericq has been well studied (Bippus et al. 2018; Hu \& Juan 2014; Krueger-Hadfield et al. 2016, 2017). Many members of the Gracilariaceae have remarkable applications including for human and animal consumption, in the pharmaceutical industry, and as medical agar (Ferdouse et al. 2018). Also some species are being cultivated for bioremediation in polyculture as part of multi-trophic aquaculture (Pereira \& Yarish 2008). 
The similar morphological characters of some Gracilariaceae species has led to problems in their taxonomy. Gracilaria chilensis (now Agarophyton chilense) in New Zealand and Chile was initially described as Gracilaria sordida (Nelson 1987) in New Zealand. Gracilaria sordida was later synonymised with G. chilensis, a species that was described a year earlier (Bird et al. 1986), based on similarities in morphology and molecular data (Bird et al. 1990). Later a molecular analysis of a sample, incorrectly, identified as $A$. chilense from the Manukau Harbour, Auckland, was grouped as sister to A. tenuistipitatum (Goff et al. 1994). ITS restriction fragment length polymorphism demonstrated that while $A$. chilense is present in New Zealand, another species was found in Manukau Harbour (Candia et al. 1999). The difference between these two species in New Zealand was further demonstrated by the presence of gigartinine (5-(3-amidinoureido)-2-aminovaleric acid) (Ito \& Hashimoto 1966) in the Manukau Harbour samples and not in A. chilense (Wilcox et al. 2001, 2007). Further phylogenetic studies demonstrated that the specimen sequenced by Goff et al. (1994) was identical with material from Australia (Byrne et al. 2002) and therefore was also placed erroneously in A. chilense. A phylogenetic study incorporating specimens from Australia, Chile and New Zealand clearly showed that there are two genetically different species incorrectly placed under the same name: A. chilense from Chile and New Zealand, and an undescribed species from Australia and New Zealand (Clade B) (Cohen et al. 2004).

The aim of this study is to formally describe the vegetative and reproductive morphology of this new species, currently known as $A$. sp. clade B from New Zealand and Australia, and compare its morphological characteristics and phylogenetic position to $A$. chilense and the other two Agarophyton species, A. tenuistipitatum and A. vermiculophyllum. This present work extends our understanding of the genus Agarophyton in New Zealand providing a number of opportunities for future research in their phylogeography, ecophysiology and biochemistry. 


\section{MATERIALS AND METHODS}

Algal sampling. Algae were collected during low tide from Australia and New Zealand (Table S1). Algal samples were pressed onto herbarium sheets and subsamples stored in silica gel. Type and voucher herbarium specimens have been deposited in the herbarium of the Museum of New Zealand Te Papa Tongarewa, Wellington, New Zealand (WELT - Thiers 2019). For morphological observation, sections were made by hand using a stainless-steel razor blade and stained with $1 \%$ aniline blue in $40 \%$ Karo® corn syrup. Photographs were obtained by microscope digital camera Olympus DP-70 (Olympus, Tokyo, Japan).

Molecular analyses. DNA extraction followed the Chelex-based technique (Zuccarello et al. 1999). A mitochondrial (the cytochrome-c-oxidase subunit I, cox1), a nuclear (internal transcript spacer 1, ITS1) marker and a plastid (the ribulose 1,5-bisphosphate carboxylase/oxygenase gene, $r b c \mathrm{~L}$ ) marker were chosen according to previous systematic studies of Gracilariaceae (Cohen et al. 2004; Gurgel et al. 2018). Genomic DNA was amplified by PCR using primer combinations for $\operatorname{cox} 1$ (Saunders 2005), for ITS1 (White et al. 1990), and for $r b c \mathrm{~L}$ (Freshwater \& Rueness 1994; Kim et al. 2010). The PCR conditions for ITS1 amplification were as follows: initial denaturation at $94^{\circ} \mathrm{C}$ for 5 mins, followed by 16 cycles of $94^{\circ} \mathrm{C}$ for $1 \mathrm{~min}, 62.5^{\circ} \mathrm{C}$ for $30 \mathrm{sec}$ and $72^{\circ} \mathrm{C}$ for $1 \mathrm{~min}$, followed by 25 cycles of $94^{\circ} \mathrm{C} / 55^{\circ} \mathrm{C} / 72^{\circ} \mathrm{C}$ for 1 min each and a final step at $72^{\circ} \mathrm{C}$ for $10 \mathrm{~min}$. The PCR profile for cox 1 and $r b c \mathrm{~L}$ were as follows: $94^{\circ} \mathrm{C}$ for $5 \mathrm{~min} ; 36$ cycles of $94^{\circ} \mathrm{C} / 45^{\circ} \mathrm{C} / 72^{\circ} \mathrm{C}$ for $1 \mathrm{~min}$ each and then a final step of $5 \mathrm{~min}$ for extension at $72^{\circ} \mathrm{C}$. The PCR amplifications were examined by electrophoresis in $1 \%$ agarose gel, and PCR products were cleaned with ExoSAP-IT (USB product, Affymetrix, Santa Clara, California, USA). Purified PCR products were Sanger sequenced commercially (Macrogen Inc., Seoul, South Korea). 
All sequences were assembled, edited and aligned using Geneious 10.2.6

(https://www.geneious.com). Additional sequences of Gracilariaceae species included in the cox1, ITS1 and $r b c \mathrm{~L}$ dataset are presented in Table S2. TCS statistical parsimony network in PopArt 1.7 (http://popart.otago.ac.nz) was used to analyze genetic diversity of ITS1. Maximum likelihood (ML) and Bayesian phylogenetic analyses were performed with all three codons partitioned for $\operatorname{cox} 1$ and $r b c \mathrm{~L}$ sequences. ML analysis was performed using the General Time Reversible + gamma model and hill-climbing algorithm. 1000 non-parametric bootstrap replicates were inferred from 10 distinct alternative runs (Felsenstein 1985) in RAxML 7.2.8 (Stamatakis 2006). Bayesian phylogenetic analysis was conducted using MrBayes 3.2.0 (Ronquist et al. 2012). Two independent sets of four Markov chain Monte Carlo (MCMC) chains were run for three million generations with sampling every 1000 generations. The two independent MCMC chains were converged when split frequency was below 0.01 . The first $25 \%$ of sampled trees as a 'burn-in' was discarded and 25,000 trees were saved to construct the consensus tree.

\section{RESULTS}

Molecular phylogeny. The $1467 \mathrm{bp} r b c \mathrm{~L}$ alignment contained 37 taxa representing the new species and all known Agarophyton species. This dataset strongly supported the new species as sister to A. tenuistipitatum with high bootstrap (100\%) and posterior probability (1.0) and as member of the genus Agarophyton (Fig. 1).

The cox 1 alignment, with a length of $654 \mathrm{bp}$, contained the holotype of the new species and representatives of all other Agarophyton species. The cox 1 alignment grouped the new species as sister to A. tenuistipitatum with strong support (Fig S1).

The 383 bp ITS1 alignment contained 13 samples of the new species and no indels were detected. Five different ribotypes were found that differed by a maximum of $2.9 \%$ (11 
bp; A3 and A5). Lineage A1 ( $n=7$, including Genbank Accession no. AY131297) was the most common ribotype and was found in Australian and New Zealand. Ribotypes A2 (AY131295) and A3 (AY131295) occurred in Australia. Lineage A4 ( $n=3)$ was the most common ribotype exclusive to Australia. Ribotype A5 (AF034265) was only present in New Zealand (Fig. 2).

The $\operatorname{cox} 1$ and $r b c \mathrm{~L}$ markers showed that the new species belongs within the genus Agarophyton and is genetically distinct from A. chilense and A. tenuistipitatum. In addition, the ITS1 marker showed that samples from Australia previously identified as A. chilense, were similar to New Zealand sequences and, therefore, belong to this new species. We proposed the new species here:

\section{Agarophyton transtasmanicum M.Preuss, N.Muangmai \& Zuccarello sp. nov.}

Figs. 3-12

DIAGNOSIS: Plants slender, 5-17 cm tall, and cylindrical $0.5-0.7 \mathrm{~mm}$ in diameter. Plants irregularly branched, sometimes alternatively. Short branchlets form around axis and branches. Thallus in cross section consists of 1-2 layers of cortical cells and 6-8 layers of medullary cells. Cell transition from cortex to medulla abrupt. Spermatangia formed in solitary or confluent shallow pits (textorii-type conceptacle). Mature cystocarps globose, pericarps rather thin. Tetrasporophytes were not observed.

TYPE LOCALITY: 3956'44.5"S, 17459'50.8"E, Whanganui River Mouth, Whanganui, North Island, New Zealand. 
HOLOTYPE: WELT A033798, male gametophyte (Fig. 3), collected 18 December 2018 by M. Preuss and G.C. Zuccarello, deposited in the Herbarium of the Museum of New Zealand Te Papa Tongarewa. Genbank Accession numbers: cox1: MN942037, ITS1: MN942043, $r b c \mathrm{~L}: \mathrm{MN} 942038$.

ISOTYPE: WELT A033797, female gametophyte (Fig. 4), collected 18 December 2018 by M. Preuss and G.C. Zuccarello, deposited in the Herbarium of the Museum of New Zealand Te Papa Tongarewa.

GENBANK ACCESSION NUMBERS: ITS1: MN942042-MN942047; rbcL: MN942038MN942041.

ETYMOLOGY: transtasmanicum refers to the distribution of the species in Australia and New Zealand across the Tasman Sea.

DISTRIBUTION: Specimens were found in the North Island of New Zealand (Auckland, Foxton, Whanganui) and Tasmania (Kingston Beach, Marion Bay) and southern Australia (Glenelg, Hindmarsh Island, Phillip Island).

DESCRIPTION: Plants attached to rocks and shells or unattached, and usually occurring in the intertidal zone in estuaries. Plants were slender, $5-17 \mathrm{~cm}$ tall, and cylindrical, $0.5-0.7 \mathrm{~mm}$ in diameter, growing in tufts or solitary (Figs. 3-4), and dark brownish red to black in colour. Branches were numerous, alternate, mostly irregular, up to 4 or 5 orders (Fig. 3). Short filiform branchlets distributed around axes and branches (Figs. 3-4). Branches and branchlets were not, or only slightly, basally constricted. Axes and branches were tapered toward the 
tips, and branch tips were often hooked (Figs. 3-4). In transverse section the thallus consisted of 1 or 2 layers of pigmented cortical cells, and 6-8 layers of medullary cells, $50-100 \mu \mathrm{m}$ in diameter (Fig. 5). There was an abrupt transition in cell size from the medulla to the cortex (Fig. 5).

Male gametophytes were more branched and larger than female thalli (Figs. 3-4).

Spermatangial conceptacles were scattered throughout the thallus (Fig. 6), forming shallow pits (textorii-type), 20-25 $\mu \mathrm{m}$ deep, 20-40 $\mu \mathrm{m}$ wide (Figs. 7-8). Spermatangia formed solitary (Fig. 7) to confluent conceptacles (Fig. 8). Cystocarps were scattered over the thallus surface. Mature cystocarps were depressed spherical, 700-900 $\mu \mathrm{m}$ in diameter, with a rostrum and constricted base (Fig. 9). Gonimoblast filaments consisted of ovoid to elongate cells, and produced outer unbranched chains of carposporangia, 5-25 $\mu \mathrm{m}$ in diameter (Fig. 10).

Nutritive filaments connected to the base of the gonimoblasts (Fig. 11). Pericarps were thin, 70-110 $\mu \mathrm{m}$ thick, and consisted of 6-10 cell layers (Fig. 12). Pericarp tissue was an outer layer of 1-3 elongate cells grading into an inner layer of 4-8 oblate to elongate branched cells (Fig. 12).

\section{DISCUSSION}

This study used morphological and molecular data to distinguish this new species, from New Zealand and Australia. Molecular data $(\operatorname{cox} 1, r b c \mathrm{~L})$ clearly indicate that our samples from New Zealand and Australia are distinct from all other Agarophyton species, and thus we propose a new species, Agarophyton transtasmanicum sp. nov. In addition, our molecular data (ITS1) have shown that our recently collected samples are conspecific with samples previously sequenced from Australia and New Zealand (Byrne et al. 2002; Goff et al. 1994), 
indicating that these sequences had been misidentified when placed in Agarophyton chilense, as previously suggested by Cohen et al. (2004).

Within the genus Agarophyton, A. transtasmanicum and A. chilense are morphologically very similar, and their similarity has led to the confusion of the two species in the field (Bird et al. 1986; Byrne et al. 2002; Nelson 1987), especially in the region of overlapping distribution range (Wilcox et al. 2007). Agarophyton transtasmanicum shares several characteristics with $A$. chilense, including branching pattern, spermatangial conceptacles, cystocarp shape, the position of nutritive filaments and pericarp arrangement (Table 1), but they may be distinguished by the number of medullary layers (6-8 cells in $A$. transtasmanicum and 8-10 cells in A. chilense), and cortex-to-medulla transition (abrupt in $A$. transtasmanicum, but relatively gradual in A. chilense). In the field, A. transtasmanicum is generally shorter than A. chilense and has hooked apices on several branch tips (Byrne et al. 2002). Despite their morphological similarity, molecular data $(r b c \mathrm{~L})$ clearly distinguish between $A$. transtasmanicum and $A$. chilense. The phylogenetic relationship of $A$. transtasmanicum and A. tenuistipitatum as sister species was also shown using the cox2-3 spacer and RUBISCO spacer (Cohen et al. 2004). Both species, A. transtasmanicum and $A$. chilense, can be found in the same locations in New Zealand, and based on currently available data only A. transtasmanicum is present in Australia.

Our phylogenetic analyses of $r b c \mathrm{~L}$ data demonstrated that $A$. transtasmanicum is closely related to A. tenuistipitatum. Morphologically, both A. transtasmanicum and A. tenuistipitatum possess often an irregular branching pattern with several branchlets and abrupt cell transition (Chang \& Xia 1976, 1988; Lewmanomont 1994; Ohno et al. 1999). The differences between the two are thallus length, the number of medullary cells and pericarp thickness (Table 1). Thalli of A. transtasmanicum are smaller in length and diameter than $A$. tenuistipitatum (Chang \& Xia 1988; Lewmanomont 1994). The main axis of $A$. 
transtasmanicum contains more medullary cell layers (6-8 cells) than A. tenuistipitatum (4-6 cells, Chang \& Xia 1988; Lewmanomont 1994). The mature cystocarps of $A$. transtasmanicum have more pericarp cell layers (6-10 cells) than A. tenuistipitatum (4-5 cells, Chang \& Xia 1988; Lewmanomont 1994). The distribution range of the two do not overlap. Agarophyton transtasmanicum is currently known to occur in southeastern Australia and New Zealand whereas A. tenuistipitatum is mostly found in China, Southeast Asia and North America (Chang \& Xia 1988; Lewmanomont 1994; Ohno et al. 1999).

Agarophyton transtasmanicum also shares a variety of common morphological features with A. vermiculophyllum, for example, thallus shape, branching pattern, cystocarp shape and anatomy (Table 1). The greatest differences between these two species is that the spermatangial conceptacle is of the textorii-type in A. transtasmanicum, and the verrucosatype (deep pot-shaped) in A. vermiculophyllum (Rueness 2005; Terada \& Yamamoto 2002). These species do not overlap in distributional ranges: A. vermiculophyllum is native to China, Korea and Japan, and introduced to the North Atlantic and north west Pacific (Bellorin et al. 2004; Kim et al. 2010; Krueger-Hadfield et al. 2018; Terada \& Yamamoto 2002).

The genus Agarophyton contains four species, including our new species, $A$. transtasmanicum. The genus was originally established on the basis of several characters, including the abrupt transition between cortex and medulla (Gurgel et al., 2018). However, the significance of the characteristic transition between cortex-medulla cells is uncertain at the genus level as it occurs as abrupt transition in A. transtasmanicum and A. tenusitipitatum, and gradual transition in A. chilense and A. vermiculophyllum (Table 1). Accordingly, we conclude that the diagnosis of cortex-medulla cell transition is flawed as a genus level character, but appears to be useful at the species level.

Our knowledge of A. transtasmanicum is still limited. As a result, further studies on the genetic diversity and population connectivity across Tasman Sea of A. transtasmanicum 
are needed to shed light on the species history, and demographic patterns. In addition, the ability of Agarophyton transtasmanicum to produce gigartinine, serving as a means of nitrogen storage, has raised interest in the possible commercial attributes of this species (Wilcox et al. 2007). Therefore A. transtasmanicum could be an ideal candidate for use in bioremediation in nitrogen loaded environments such as polluted rivers and in polyculture as part of multi-trophic aquaculture. Future physiological studies are needed to understand more about the responses of $A$. transtasmanicum to environmental conditions.

\section{ACKNOWLEDGEMENTS}

This work was supported by Victoria University of Wellington (MP, GZ), NIWA SSIF funding (Coasts and Oceans Research Programme 2, Marine Biological Resources) (WAN) The staff of the herbarium of the Museum of New Zealand Te Papa Tongarewa (WELT) are thanked for their assistance. MLG and WAN were supported by FONDECYT Regular Grant\#1170541 (CONICYT, Chile). Special thanks goes to the GCRF GlobalSeaweedSTAR program for providing travel funds (GSS/TF/006) to NM. 


\section{REFERENCES}

Abbott I.A. \& McDermid K.J. 2004. Taxonomy of economic seaweeds: with reference to the Pacific and other locations. Volume IX. University of Hawaii \& Sea Grant College Program, Hawaii, USA. 281 pp.

Bellorin A.M., Oliveira M.C. \& Oliveira E.C. 2004. Gracilaria vermiculophylla: A western Pacific species of Gracilariaceae (Rhodophyta) first recorded from the eastern Pacific. Phycological Research 52:69-79. DOI: 10.1111/j.1440-183.2004.00330.x.

Bippus P.M., Krueger-Hadfield S.A. \& Sotka E.E. 2018. Palatability of an introduced seaweed does not differ between native and non-native populations. Marine Biology 165. DOI: 10.1007/s00227-018-3291-5.

Bird C.J., McLachlan J. \& Oliveira E.C. de 1986. Gracilaria chilensis sp. nov. (Rhodophyta, Gigartinales), from Pacific South America. Canadian Journal of Botany 64:2928-34. DOI: 10.1139/b86-387.

Bird C.J., Nelson W.A., Rice E.L., Ryan K.G. \& Villemur R. 1990. A critical comparison of Gracilaria chilensis and G. sordida (Rhodophyta, Gracilariales). Journal of Applied Phycology 2:375-82. DOI: 10.1007/BF02180928.

Byrne K., Zuccarello G.C., West J., Liao M.-L. \& Kraft G.T. 2002. Gracilaria species (Gracilariaceae, Rhodophyta) from southeastern Australia, including a new species, Gracilaria perplexa sp. nov.: Morphology, molecular relationships and agar content. Phycological Research 50:295-311. DOI: 10.1046/j.1440-1835.2002.00282.x.

Candia A., González M.A., Montoya R., Gómez P. \& Nelson W. 1999. Comparison of ITS RFLP patterns of Gracilaria (Rhodophyceae, Gracilariales) populations from Chile and New Zealand and an examination of interfertility of Chilean morphotypes. Journal of Applied Phycology 11:185-93. DOI: 10.1023/A:1008094009045.

Chang C.F. \& Xia B. 1976. Studies on Chinese species of Gracilaria. Studia Marina Sinica 
11:91-163.

Chang C.F. \& Xia B.M. 1988. On two new Gracilaria (Gigartinales, Rhodophyta) from South China. In: Taxonomy of economic seaweeds with reference to some Pacific and Caribbean species, vol. 2. (Ed. by I.A. Abbott), pp. 127-9. California Sea Grant College Program, California, USA.

Cohen S., Faugeron S., Martínez E.A., Correa J.A., Viard F., Destombe C. \& Valero M. 2004. Molecular identification of two sibling species under the name Gracilaria chilensis (Rhodophyta, Gracilariales). Journal of Phycology 40:742-7. DOI: 10.1111/j.1529-8817.2004.03203.x.

Felsenstein J. 1985. Confidence limits on phylogenies: an approach using the bootstrap. Evolution 39:783-91. DOI: 10.1111/j.1558-5646.1985.tb00420.x.

Ferdouse F., Holdt S.L., Smith R., Murúa P. \& Yang Z. 2018. The global status of seaweed production, trade and utilization. Food and agriculture organization of the United Nations, Rome, Italy. 114 pp.

Freshwater D.W. \& Rueness J. 1994. Phylogenetic relationships of some European Gelidium (Gelidiales, Rhodophyta) species, based on $r b c \mathrm{~L}$ nucleotide sequence analysis. Phycologia 33:187-94. DOI: 10.2216/i0031-8884-33-3-187.1.

Goff L.J., Moon D.A. \& Coleman A.W. 1994. Molecular delineation of species and species relationships in the red algal agarophytes Gracilariopsis and Gracilaria (Gracilariales). Journal of Phycology 30:521-37. DOI: 10.1111/j.00223646.1994.00521.x.

Guiry M.D., Norris J.N., Fredericq S. \& Gurgel C.F.D. 2018. Crassiphycus Guiry, Gurgel, J.N.Norris \& Fredericq, gen. nov., a replacement name for Crassa Gurgel, J.N.Norris \& Fredericq, nom. inval. (Gracilariaceae, Rhodophyta), with some additional nomenclatural notes. Notulae Algarum 82:1-4. DOI: 10.1111/jpy.12281. 
Gurgel C.F.D. \& Fredericq S. 2004. Systematics of the Gracilariaceae (Gracilariales, Rhodophyta): A critical assessment based on $r b c \mathrm{~L}$ sequence analyses. Journal of Phycology 40:138-59. DOI: 10.1111/j.0022-3646.2003.02-129.x.

Gurgel C.F.D., Norris J.N., Schmidt W.E., Le H.N. \& Fredericq S. 2018. Systematics of the Gracilariales (Rhodophyta) including new subfamilies, tribes, subgenera, and two new genera, Agarophyton gen. nov. and Crassa gen. nov. Phytotaxa 374:1. DOI: 10.11646/phytotaxa.374.1.1.

Hu Z.M. \& Juan L.B. 2014. Adaptation mechanisms and ecological consequences of seaweed invasions: A review case of agarophyte Gracilaria vermiculophylla. Biological Invasions 16:967-76. DOI: 10.1007/s10530-013-0558-0.

Iha C., Grassa C.J., Lyra G.d.M., Davis C.C., Verbruggen H. \& Oliveira M.C. 2018. Organellar genomics: a useful tool to study evolutionary relationships and molecular evolution in Gracilariaceae (Rhodophyta). Journal of Phycology 54:775-87. DOI: 10.1111/jpy.12765.

Ito K. \& Hashimoto Y. 1966. Gigartinine: A new amino-acid in red algae. Nature 211:417. DOI: $10.1038 / 211417 \mathrm{a} 0$.

Kim M.-S., Kim S.-Y. \& Nelson W. 2010. Symphyocladia lithophila sp. nov. (Rhodomelaceae, Ceramiales), a new Korean red algal species based on morphology and $r b c$ L sequences. Botanica Marina 53:233-41. DOI: 10.1515/BOT.2010.031.

Kim S.-Y., Weinberger F. \& Boo S.-M. 2010. Genetic data hint at a common donor region for invasive Atlantic and Pacific populations of Gracilaria vermiculophylla (Gracilariales, Rhodophyta). Journal of Phycology 46:1346-9. DOI: 10.1111/j.15298817.2010.00905.x.

Krueger-Hadfield S.A., Kollars N.M., Byers J.E., Greig T.W., Hammann M., Murray D.C., Murren C.J., Strand A.E., Ryuta T., Weinberg F. \& Sotka E.E. 2016. 
Invasion of novel habitats uncouples haplo-diplontic life cycles. Molecular Ecology 25:3801-16. DOI: 10.1111/mec.13718.

Krueger-Hadfield S.A., Kollars N.M., Strand A.E., Byers J.E., Shainker S.J., Terada R., Greig T.W., Hammann M., Murray D.C., Weinberg F. \& Sotka E.E. 2017. Genetic identification of source and likely vector of a widespread marine invader. Ecology and Evolution 7:4432-47. DOI: 10.1002/ece3.3001.

Krueger-Hadfield S.A., Stephens T.A., Ryan W.H. \& Heiser S. 2018. Everywhere you look, everywhere you go, there's an estuary invaded by the red seaweed Gracilaria vermiculophylla (Ohmi) Papenfuss, 1967. BioInvasions Records 7:343-55. DOI: 10.3391/bir.2018.7.4.01.

Lewmanomont K. 1994. The species of Gracilaria from Thailand. In: Taxonomy of Economic Seaweeds, vol. 4. (Ed. by I.A. Abbott), pp. 135-48. California Sea Grant College Program, California, USA.

Lyra G.d.M., Costa E.d.S., de Jesus P.B., de Matos J.C.G., Caires T.A., Oliveira M.C., Oliveira E.C., Xi Z., Nunes J.M.d.C. \& Davis C.C. et al. 2015. Phylogeny of Gracilariaceae (Rhodophyta): Evidence from plastid and mitochondrial nucleotide sequences. Journal of Phycology 51:356-66. DOI: 10.1111/jpy.12281.

Nelson W.A. 1987. The New Zealand species of Gracilaria Greville (Rhodophyta, Gigartinales). New Zealand Journal of Botany 25:87-98. DOI: 10.1080/0028825X.1987.10409958.

Ohmi H. 1956. Contributions to the knowledge of Gracilariaceae from Japan, II. On a new species of the genus Gracilariopsis with some considerations on its ecology. Bulletin of the Faculty of Fisheries Hokkaido University 6:271-9.

Ohno M., Terada R. \& Yamamoto H. 1999. The species of Gracilaria from Vietnam. In: Taxonomy of Economic Seaweeds with Reference to Some Pacific Species, vol. 7. (Ed. 
by I.A. Abbott), pp. 99-111. California Sea Grant College System, California, USA. Pereira R. \& Yarish C. 2008. Mass production of marine macroalgae. In: Encyclopedia of Ecology, vol. 3 (Ed. by Jørgensen S.E. \& Fath B.D.), pp. 2236-47. Elsevier, Oxford, UK.

Ronquist F., Teslenko M., van der Mark P., Ayres D.L., Darling A., Höhna S., Larget B., Liu L. Suchard M.A. \& Huelsenbeck J.P. 2012. MrBayes 3.2: Efficient Bayesian phylogenetic inference and model choice across a large model space. Systematic Biology 61:539-42. DOI: 10.1093/sysbio/sys029.

Rueness J. 2005. Life history and molecular sequences of Gracilaria vermiculophylla (Gracilariales, Rhodophyta), a new introduction to European waters. Phycologia 44:120-8. DOI: 10.2216/0031-8884(2005)44[120;LHAMSO]2.0.CO;2.

Saunders G.W. 2005. Applying DNA barcoding to red macroalgae: a preliminary appraisal holds promise for future applications. Philosophical Transactions of the Royal Society B: Biological Sciences 360:1879-88. DOI: 10.1098/rstb.2005.1719.

Stamatakis A. 2006. RAxML-VI-HPC: maximum likelihood-based phylogenetic analyses with thousands of taxa and mixed models. Bioinformatics 22:2688-90. DOI: 10.1093/bioinformatics/btl446.

Terada R. \& Yamamoto H. 2002. Review of Gracilaria vermiculophylla and other species in Japan and Asia. In: Taxonomy of Economic Seaweeds with Reference to Some Pacific Species, Vol. 8. (Ed. by I.A. Abbott), pp. 215-24. California Sea Grant College, California, USA.

Thiers B. 2019. Index Herbariorum: a global directory of public herbaria and associated staff. New York Botanical Garden's Virtual Herbarium. Available at: http://sweetgum.nybg.org/ih/.

White T.J., Bruns T., Lee S. \& Taylor J. 1990. Amplification and direct sequencing of fungal 
ribosomal RNA genes for phylogenetics. In: PCR Protocols: A Guide to Methods and Applications (Ed. M.A. Innis, D.H. Gelfand, J.J. Snin-sky \& T.J. White), pp. 315-22. Academic Press, Orlando, Florida.

Wilcox S.J., Barr N., Broom J., Furneaux R.H. \& Nelson W.A. 2007. Using gigartinine to track the distribution of an alien species of Gracilaria in New Zealand. Journal of Applied Phycology 19:313-23. DOI: 10.1007/s10811-006-9138-3.

Wilcox S.J., Bloor S.J., Hemmingson J.A., Furneaux R.H. \& Nelson W.A. 2001. The presence of gigartinine in a New Zealand Gracilaria species. Journal of Applied Phycology 13:409-13. DOI: 10.1007/s10811-006-9138-3.

Zuccarello G.C., West J.A., Kamiya M. \& King R.J. 1999. A rapid method to score plastid haplotypes in red seaweeds and its use in determining parental inheritance of plastids in the red alga Bostrychia (Ceramiales). Hydrobiologia 401:207-14. DOI:

10.1023/A:1003706931897. 
Table 1. Comparison of some morphological characteristics of Agarophyton transtasmanicium sp. nov. with all other Agarophyton species.

\begin{tabular}{|c|c|c|c|c|}
\hline Characters & $\begin{array}{l}\text { Agarophyton } \\
\text { transtasmanicum } \\
\text { sp. nov. }{ }^{1,2}\end{array}$ & $\begin{array}{l}\text { Agarophyton } \\
\text { chilense }^{3,4,5}\end{array}$ & $\begin{array}{l}\text { Agarophyton } \\
\text { tenuistipitatum }^{6,7,8,9}\end{array}$ & $\begin{array}{l}\text { Agarophyton } \\
\text { vermiculophyllum }^{10,11,12,13,14,15}\end{array}$ \\
\hline $\begin{array}{l}\text { Thallus length } \\
\text { (cm) }\end{array}$ & $5-20$ & $\begin{array}{l}\text { Usually } 10-60, \\
\text { sometimes reaches } 1.5 \\
\mathrm{~m}\end{array}$ & $\begin{array}{l}\text { Usually } 20-40 \text {, } \\
\text { sometimes reaches } 1 \mathrm{~m}\end{array}$ & Usually $10-30$, sometimes reaches to $1 \mathrm{~m}$ \\
\hline $\begin{array}{l}\text { Thallus width } \\
(\mathrm{mm})\end{array}$ & $0.5-0.9$ & $0.5-2.0$ & $0.5-1.5$ & $1-2 \mathrm{~mm}$, sometimes reaches to 5 \\
\hline $\begin{array}{l}\text { Branching } \\
\text { pattern }\end{array}$ & $\begin{array}{l}\text { Mostly irregular, } \\
\text { sometimes alternate, up to } \\
5 \text { orders, }\end{array}$ & $\begin{array}{l}\text { Variable, irregular or } \\
\text { alternate, up to } 4 \text { orders }\end{array}$ & $\begin{array}{l}\text { Mostly irregular, } \\
\text { sometimes alternate, up to } \\
3 \text { orders }\end{array}$ & $\begin{array}{l}\text { Alternate or irregular, sometimes second or } \\
\text { subdichotomous }\end{array}$ \\
\hline Branchlets & $\begin{array}{l}\text { Many around axis } \\
\text { and branches }\end{array}$ & $\begin{array}{l}\text { Some around lower } \\
\text { portion of axis and } \\
\text { main branches }\end{array}$ & $\begin{array}{l}\text { Many around axis and } \\
\text { branches }\end{array}$ & Some around axis and branches \\
\hline Cortical layer & $1-3$ cells & $1-2$ cells & $1-2$ cells & $1-2$ cells \\
\hline
\end{tabular}




\begin{tabular}{|c|c|c|c|c|}
\hline Medullary & $6-8$ cells & $8-10$ cells & $4-6$ cells & $6-13$ cells \\
\hline Male structure & textorii-type & textorii-type & textorii-type & verrucosa-type \\
\hline Cystocarp & Depressed sphere, with a & Depressed sphere, with & Sphere, with a rostrate & Sphere, with a slight rostrate ostiole and \\
\hline shape & constricted base & and constricted base & base & \\
\hline $\begin{array}{l}\text { Gonimoblast } \\
\text { cell shape }\end{array}$ & Round to elongate & Round to isodiametric & Round to isodiametric & Mostly round \\
\hline Distribution & Southern Australia and & South America and & China, Southeast Asia and & Japan, Korea and China, and introduced to \\
\hline & New Zealand & New Zealand & North America & $\begin{array}{l}\text { some locations in North Atlantic and North } \\
\text { West Pacific }\end{array}$ \\
\hline
\end{tabular}


${ }^{1}$ This study; ${ }^{2}$ Byrne et al. 2002; ${ }^{3}$ Bird et al. $1986 ;{ }^{4}$ Nelson 1987 (as Gracilaria sordida); ${ }^{5}$ Bird et al. 1990; ${ }^{6}$ Chang \& Xia 1976; ${ }^{7}$ Chang \& Xia 1988;

${ }^{8}$ Lewmanomont 1994; ${ }^{9}$ Ohno et al. 1999; ${ }^{10}$ Ohmi 1956 (as Gracilariopsis vermiculophylla); ${ }^{11}$ Terada \& Yamamoto 2002; ${ }^{12}$ Bellorin et al. 2004 ;

${ }^{13}$ Rueness 2005; ${ }^{14}$ Kim et al. 2010; ${ }^{15}$ Krueger-Hadfield et al. 2018. 


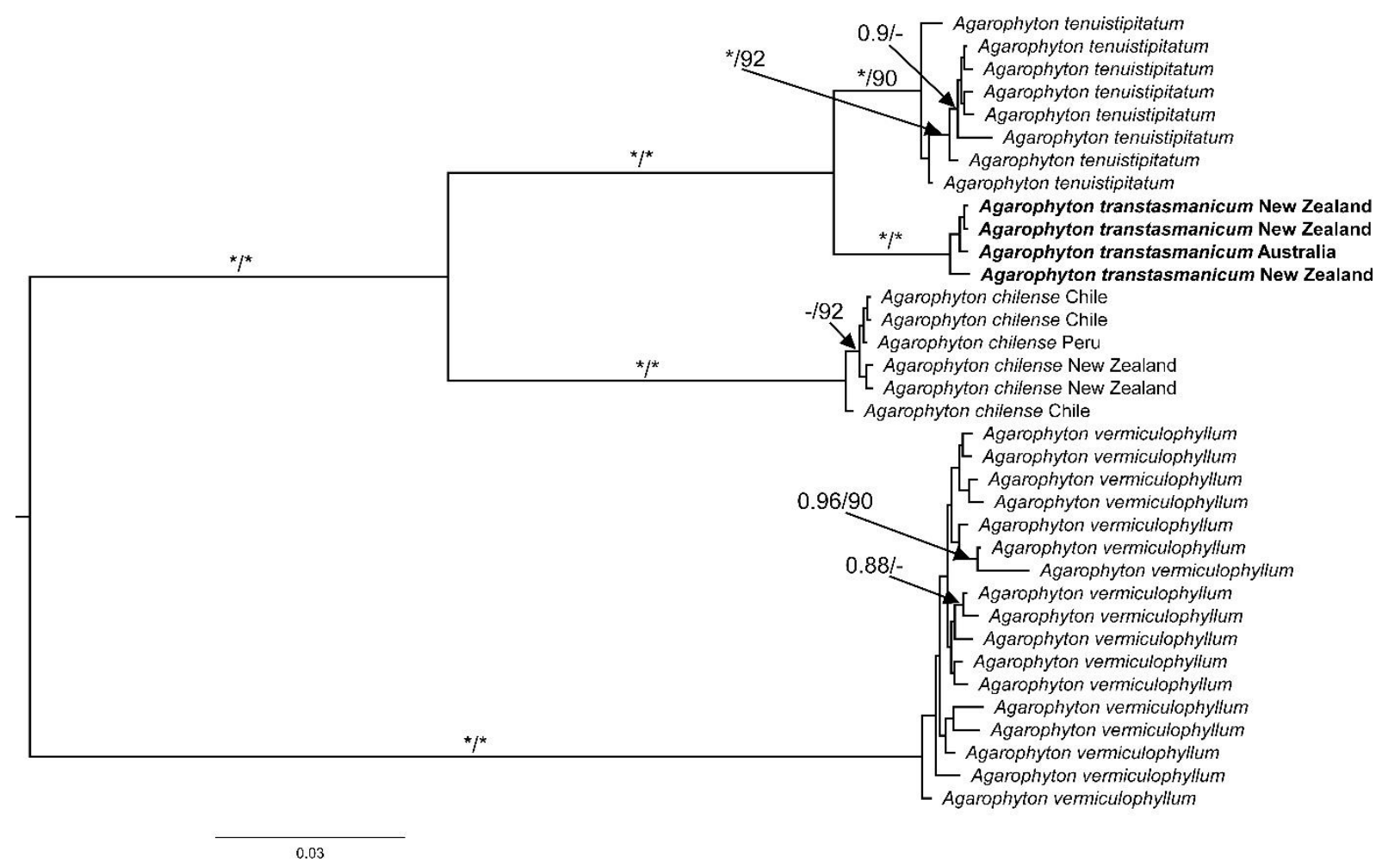

Fig. 1. Bayesian topology of $r b c \mathrm{~L}$ sequences for Agarophyton transtasmanicum sp. nov., A.

chilense, A. tenuistipitatum and A. vermiculophyllum (Table S2). Specimens of $A$.

transtasmanicum are highlighted in bold. Country of collections are given for $A$.

transtasmanicum and A. chilense. Asterisks indicate posterior probability value of 1.00 and bootstrap value of $100 \%$. Values $<0.85$ posterior probability and $<85 \%$ ML bootstrap not shown. Crassiphycus changii and Crassiphycus firmus were used as outgroups but removed to facilitate representation. 


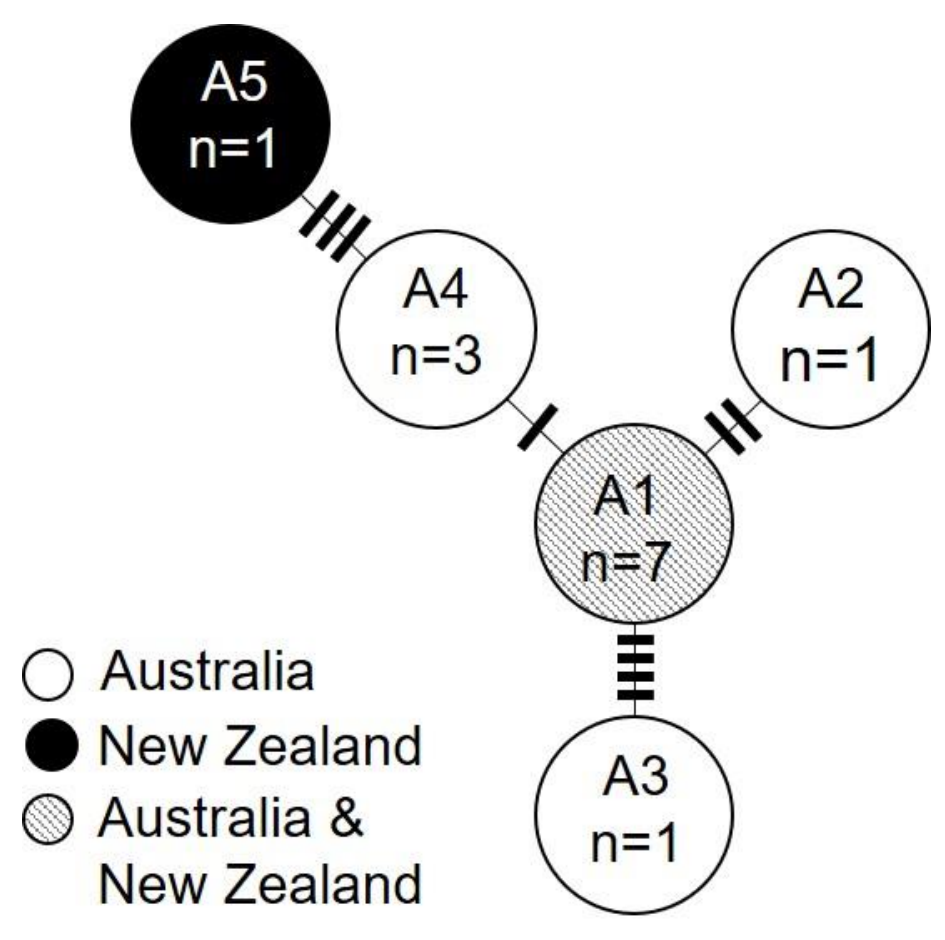

Fig. 2. ITS1 ribotype network of Agarophyton transtasmanicum sp. nov. with five different ribotypes represented (A1-A5). Cross lines represents one mutational step. Number of samples (n) with ribotype indicated and location of ribotypes shown: Australia (white), New Zealand (black), and Australia and New Zealand (cross-hatch). 
3

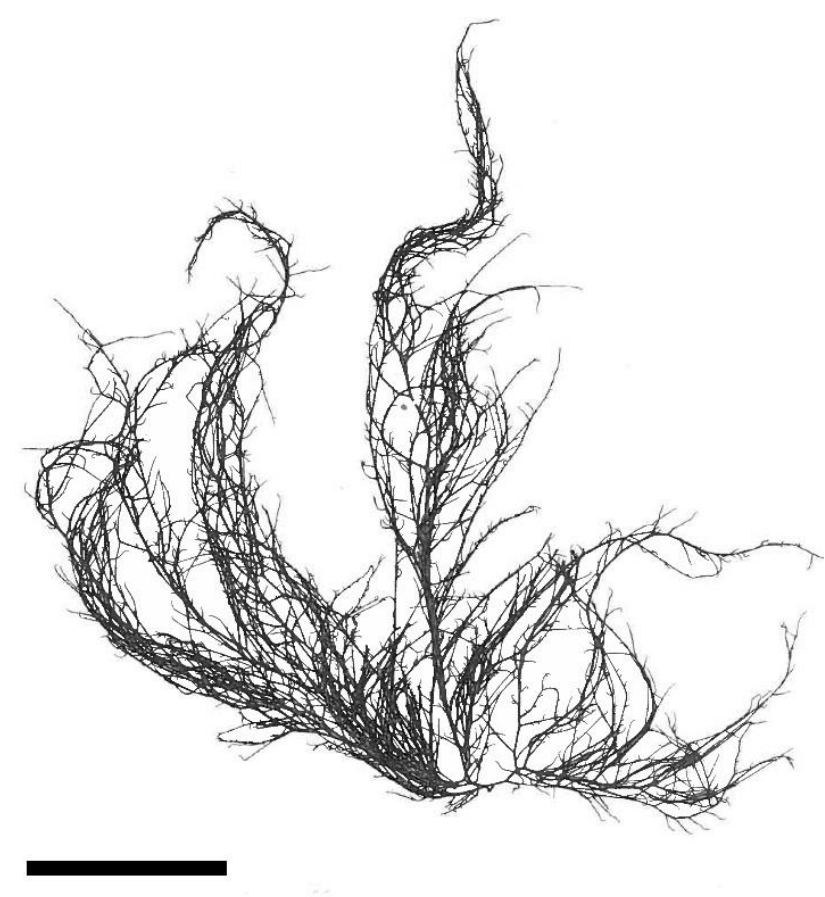

4
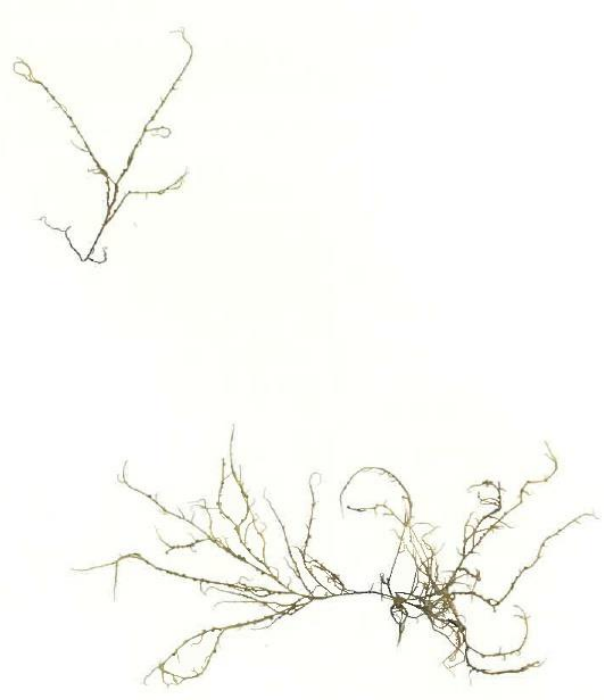

Figs. 3-4. Habits of Agarophyton transtasmanicum sp. nov. from Whanganui River Mouth,

New Zealand. Fig. 3. Holotype, male gametophyte (WELT A033798). Scale bar $=4 \mathrm{~cm}$. Fig.

4. Isotype, female gametophyte (WELT A033797). Scale bar $=3 \mathrm{~cm}$. 

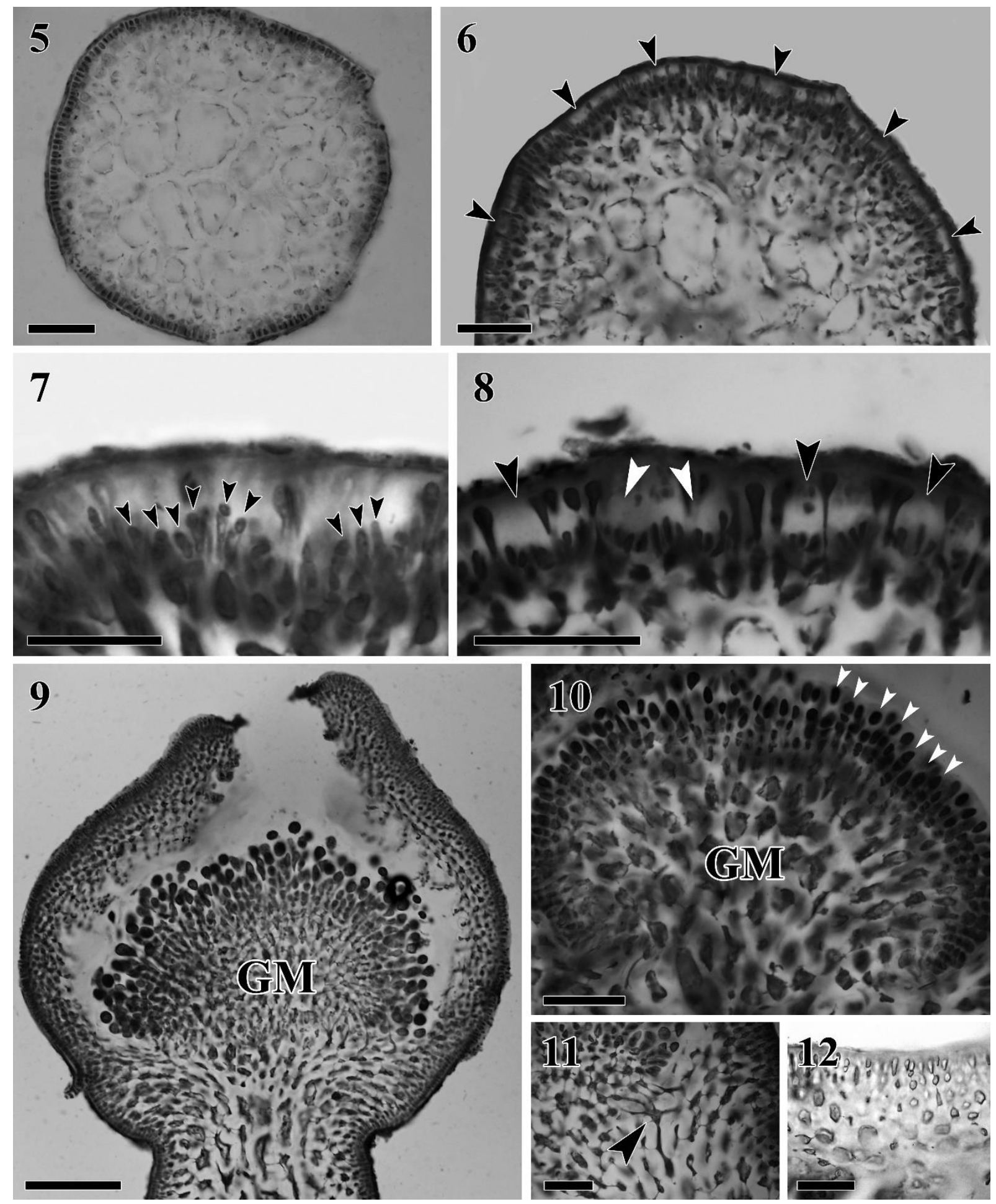

Figs. 5-12. Detailed morphological feature of Agarophyton transtasmanicum sp. nov. Fig. 5.

Cross-section of main axis showing abrupt transition from cortex to medulla. Scale bar $=150$

$\mu \mathrm{m}$. Fig. 6. Cross-section of male gametophyte showing textorii-type spermatangial

conceptacles (arrowheads). Scale bar $=100 \mu \mathrm{m}$. Fig. 7. A young spermatangial conceptacle 
bearing spermatia (arrowheads). Scale bar $=40 \mu \mathrm{m}$. Fig. 8. Mature confluent (white arrowheads) and solitary spermatangial conceptacles (black arrowheads). Scale bar $=50 \mu \mathrm{m}$. Fig. 9. Cross-section of mature cystocarp, with rostrum and constricted base, showing gonimoblast filament (GM). Scale bar $=200 \mu \mathrm{m}$. Fig. 10. Close-up view of gonimoblast (GM) consisting of ovoid to elongate cells with the outer unbranched chains of carposporangia (arrowheads). Scale bar $=100 \mu \mathrm{m}$. Fig. 11. Cystocarp base showing nutritive filament (arrowhead) connecting the gonimoblast to the pericarp. Scale bar $=40 \mu \mathrm{m}$. Fig. 12 . Pericarp tissue consisting of outer elongate cell and inner roundish cells. Scale bar $=40 \mu \mathrm{m}$. 
Table S1. Samples collected for molecular and morphological analysis of A. transtasmanicum in Australia and New Zealand. Genbank Accession no. indicated in sequenced regions.

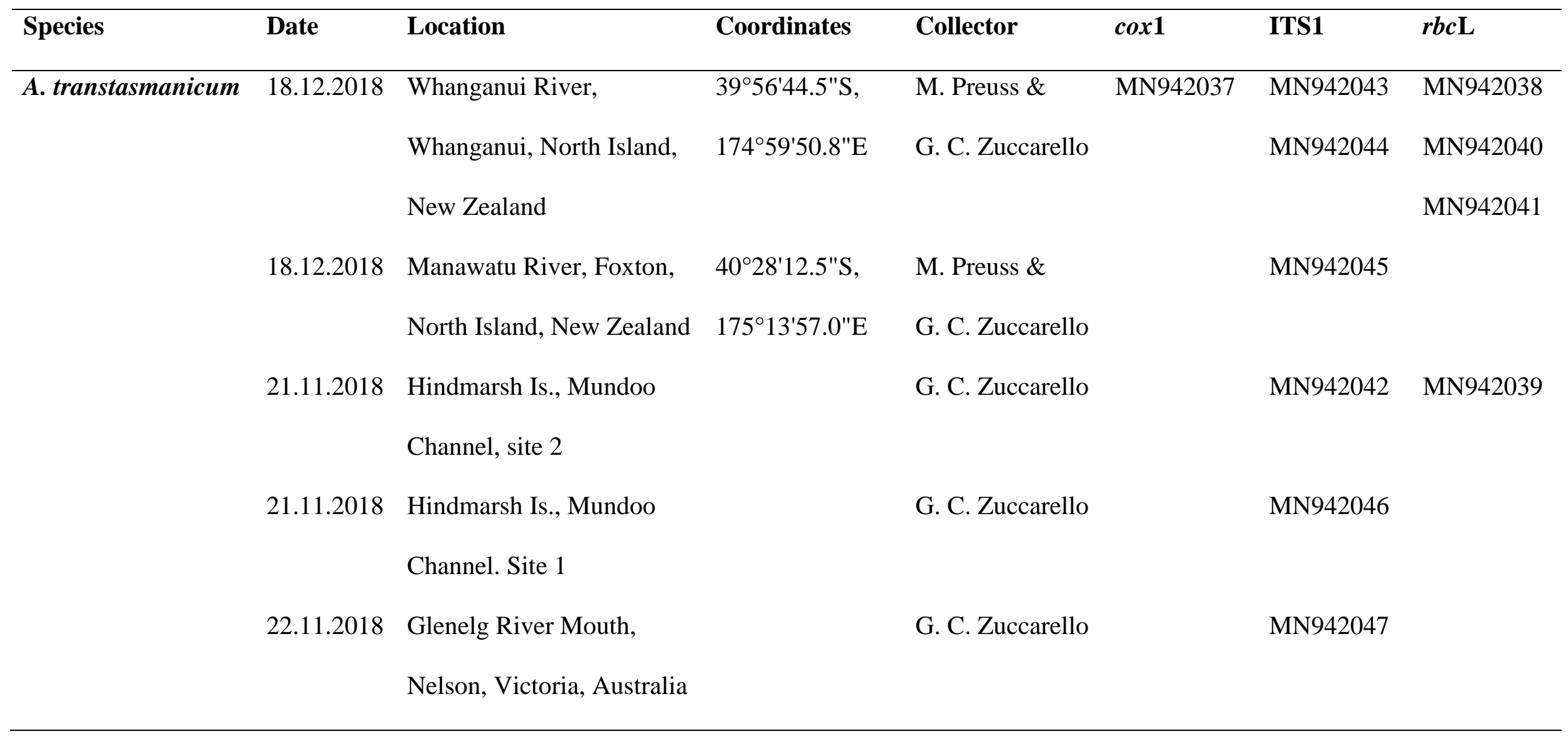




$\begin{array}{lll}\text { 10.02.19 } & \text { Browns River, Kingston } & 42^{\circ} 58^{\prime} 39.9^{\prime \prime S}, \\ & \text { Beach, Tasmania, } & 147^{\circ} 19^{\prime} 42.4^{\prime \prime} \mathrm{E} \\ & & \end{array}$

M. Preuss

XXXXXX

Australia 
Table S2. List of species and Genbank Accession numbers for $\operatorname{cox} 1$, ITS1 and $r b c \mathrm{~L}$ sequences from Genbank used in molecular analyses.

\section{Species}

Genbank Accession numbers

\begin{tabular}{|c|c|c|c|}
\hline & $\underline{\operatorname{cox} 1}$ & $\underline{\text { ITS1 }}$ & $\underline{r b c \mathrm{~L}}$ \\
\hline \multirow[t]{6}{*}{ Agarophyton chilense } & KP728466 & & AY049396 \\
\hline & MF41962 & & DQ095784 \\
\hline & NC 026831 & & HQ998843 \\
\hline & & & HQ998848 \\
\hline & & & KP857578 \\
\hline & & & MH760419 \\
\hline \multirow[t]{4}{*}{ Agarophyton transtasmanicum sp. nov. } & & AF034265 & \\
\hline & & AY131295 & \\
\hline & & AY131296 & \\
\hline & & AY131297 & \\
\hline \multirow[t]{8}{*}{ Agarophyton tenuistipitatum } & JQ026074 & & DQ119743 \\
\hline & JQ026076 & & EF434906 \\
\hline & JQ407638 & & EU380718 \\
\hline & JQ407639 & & JN605793 \\
\hline & JQ407641 & & KF214701 \\
\hline & JQ407649 & & MH760420 \\
\hline & JQ407653 & & MH760421 \\
\hline & & & MH760425 \\
\hline \multirow[t]{3}{*}{ Agarophyton vermiculophyllum } & GQ292865 & & AY049314 \\
\hline & HQ3220449 & & AY725172 \\
\hline & HQ322048 & & DQ095822 \\
\hline
\end{tabular}




\begin{tabular}{|c|c|c|}
\hline & HQ322086 & EF434907 \\
\hline & HQ412552 & EU600293 \\
\hline & JQ407598 & EU605702 \\
\hline & JQ407609 & JQ407698 \\
\hline & JQ619143 & JQ407699 \\
\hline & JQ736334 & JQ407701 \\
\hline & JQ794749 & JQ407704 \\
\hline & JQ794751 & JQ728687 \\
\hline & JQ794756 & JQ768762 \\
\hline & JQ794757 & JQ768764 \\
\hline & JQ794759 & JQ768767 \\
\hline & KF367746 & JQ768769 \\
\hline & KF789527 & JQ768770 \\
\hline & KJ526627 & HQ880644 \\
\hline Crassiphycus changii & KY009863 & AY049388 \\
\hline Crassiphycus firmus & KY315284 & DQ119739 \\
\hline
\end{tabular}




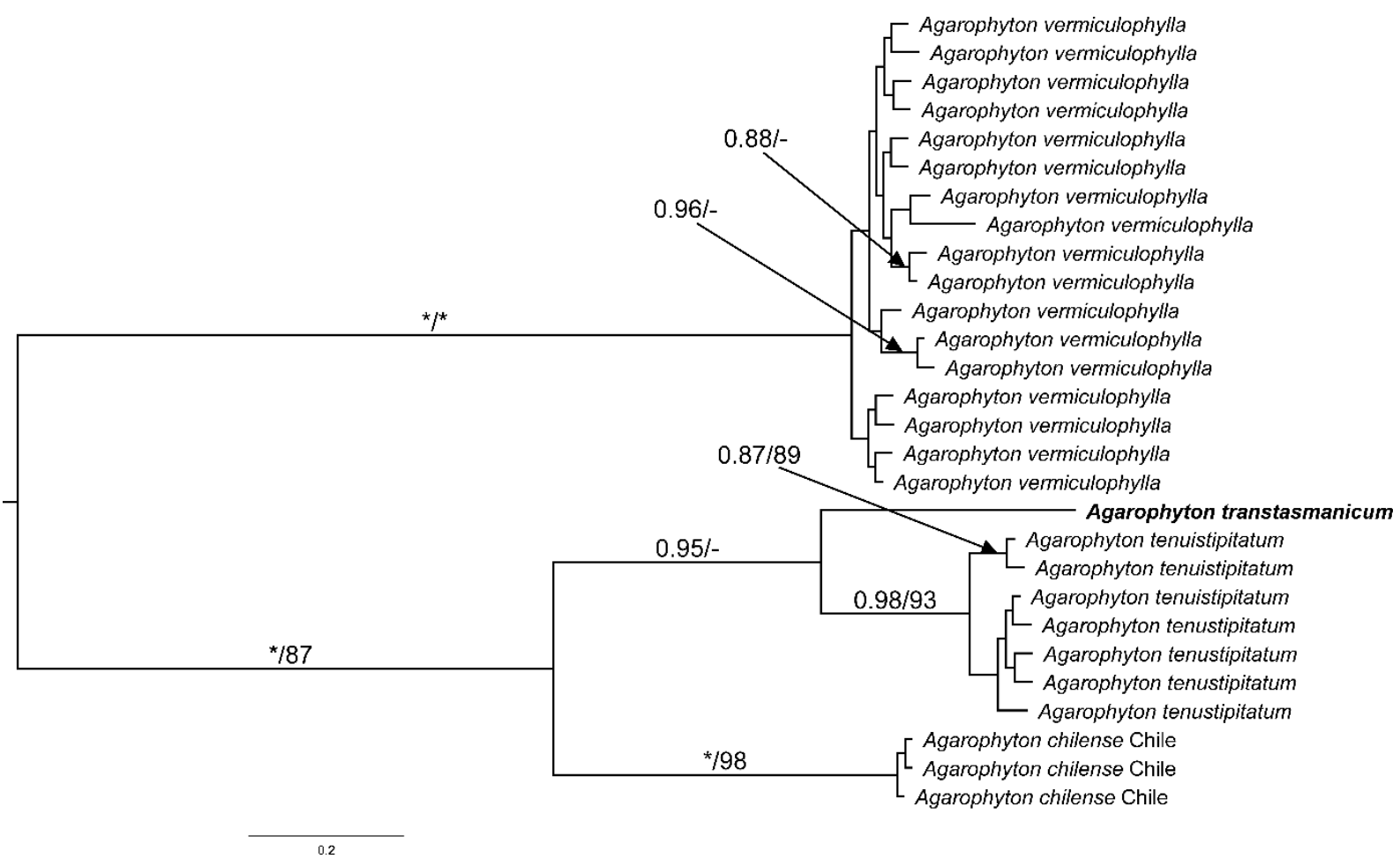

Fig. S1. Bayesian topology of partial cox 1 sequences for Agarophyton transtasmanicum sp.

nov., A. chilense, A. tenuistipitatum and A. vermiculophyllum (Table S2). The holotype of $A$. transtasmanicum is highlighted in bold. Asterisks indicate posterior probability value of 1.00 and bootstrap value of $100 \%$. Values $<0.85$ posterior probability and $<85 \%$ ML bootstrap not shown. Crassiphycus changii and Crassiphycus firmus were used as outgroups but removed to facilitate representation. 